\title{
Air-dried neem leaf extract: effects on the growth performance and blood profile of
} broiler chicken

${ }^{1}$ Egbeyale, L. T*., ${ }^{1}$ Ijaduola, O. A., ${ }^{1}$ Sogunle, O. M., ${ }^{2}$ Sonibare, A. O., ${ }^{1}$ Ayo-Ajasa, O. Y., Adeleye, O. O. and ${ }^{3}$ Adewole, F. A.

${ }^{1}$ Department of Animal Production and Health,

${ }^{2}$ Department of Veterinary Medicine and Surgery, ${ }^{3}$ Institute of Food Security,

Environmental Resources and Agricultural Research

Federal University of Agriculture, P.M.B. 2240, Abeokuta, Nigeria

Corresponding author: *egbeyalelt@funaab.edu.ng. Phone No: 08060743664

Abstract

This study was conducted to evaluate the efficacy of aqueous extract of air-dried neem leaves on growth performance and blood profile of broiler chickens. One hundred and sixty (160) broiler chicks were used for the experiment and were intensively managed. The chicks were randomly assigned into four treatment groups administered, 30, 40 and 50mLs of 4\% aqueous neem leaf extracts and defined as T1, T2, T3 and T4, respectively. Growth parameters (daily weight gain, feed intake, water intake and feed conversion ratio) and both haematological and serum indices were measured. Data were subjected to One-way Analysis of Variance and significant means were separated by Duncan Multiple Range Test at $95 \%$ probability. Result showed a significant $(p<0.05)$ influence of aqueous neem leaf extract on feed conversion ratio only at starter phase. The birds on $50 \mathrm{mLs}$ aqueous neem leaf extract had poorest (1.58) feed conversion ratio while best (1.48) values were observed from those in the control and $40 \mathrm{mLs}$. It also showed that neem leaf extracts had no significant $(P>0.05)$ effect on all the haemetaological parameters and serum indices at both starter and finisher phases. It was concluded that the use of air-dried neem leaf extract can be adopted as a replacement to antibiotics in broiler chicken production without any adverse effect on their growth performance and blood status.

Keywords: neem leaf extract, performance, blood status, broiler chicken

\section{Introduction}

The importance of poultry industry to the socio-economic development of any country cannot be overemphasized as a result of its ability to provide animal protein at a relatively shorter duration at reasonable cost to the consumer. Many synthetic drugs and growth promoters are supplemented to the diets of broiler chickens to effect rapid growth, but their use have shown many disadvantages like high cost, adverse side effect on health of birds and long residual properties (Nayaka et al., 2012). Exploring new antibiotics from the medicinal plants is a priority resistance to increase the production of broilers. In Nigeria, a good number of different herbs and plants parts ranging from leaves meal and extracts, seeds, fruits and tree barks have been used in researches as alternatives to the conventional feeds, feedstuff, growth promoters and antibiotics. In some recent researches, Aspilia africana, flamboyant seeds, bitter kola, Amarathus cruentus, Mucuna utilis, Azadirachta indica, Curcuma longa and Cinnamomum zylenicum and host of others have been successfully used as supplement to enhance the health and performance of livestock particularly monogastric animals including poultry (Rahman et al., 2014).

Neem tree is a widely researched tree that has attracted world-wide recognition due to its vast range of medicinal potentials like antibacterial, antiviral, antifungal, Antiprotozoal, Hepatoprotective and anti- 


\section{Air-dried neem leaf extract}

coccidial effect in broiler chickens and used as pesticide (Akpan et al., 2008). Various other properties have been documented in respect of its many bioactive components (Akpan et al., 2008) that may also influence haematological and serum biochemical parameters in animals. Growth performances and blood profiles are important indices of physiological state of animals (Khan and Zafer, 2005). Serum biochemistry and haematological features have attracted many researchers in order to make clinical predictions of the health status in animals, birds and even humans. The blood picture varies with certain conditions such as stress, infections and toxicity and blood constituents provide valuable media for clinical investigations and nutritional evaluation (Khan and Zafer, 2005). Therefore, the present study is designed with the main objective of determining the effect of neem leaf extract on growth performance, haematology and serum biochemical indices of broiler chickens.

\section{Materials and methods Experiment site}

The experiment was carried out at the poultry unit of the Directorate of University Farm of the Federal University of Agriculture, Abeokuta, Ogun State, Nigeria. The area lies on latitude $7^{\circ} 10^{\prime} \mathrm{N}$ and longitude $3^{\circ} 2^{\prime} \mathrm{E}$, it received a mean precipitation of $1037 \mathrm{~mm}$ per annual an average temperature of $34.7^{\circ} \mathrm{C}$ and an average relative humidity of $82 \%$ throughout the year (Google Earth, 2017).

\section{Aqueous extraction of neem leaf}

Fresh neem leaves were harvested and air dried until it became very dry. One litre of boiled water was added to $40 \mathrm{~g}$ of air-dried neem leaf for 5 hours which was later sieved to get the neem leaf extract. The prepared extract was further diluted at the rates $0,30,40$ and $50 \mathrm{ml}$ in one litre of water.

\section{Experimental animals and their management}

One hundred and sixty day-old broiler chicks were purchased and were allocated into four treatment groups of forty birds each. Each treatment was sub-divided into four replicates with ten birds per replicate. The birds were fed ad-libitum throughout the experimental period. Diet composition is presented in Table 1. Only the birds in control group were given antibiotics.

\section{Data collection}

The birds were weighed upon arrival to get their initial weight while they were also weighed on weekly basis and recorded appropriately so as to ascertain their weight gain. Their feed intake and water intake were measured and the feed conversion ratio was calculated. At 28th and 49th day, two birds were selected and marked from each replicate for blood collection. With a $4 \mathrm{ml}$ syringe fitted with a 24 -gauge sterile hypodermic needle, $5 \mathrm{mLs}$ of blood was carefully drawn from the jugular vein in the neck region. $2 \mathrm{mLs}$ of the blood was put into a sterilized bottle containing Ethylene diamine tetra acetic acid (EDTA) as anticoagulant, and mixed gently to prevent coagulation, while the rest of the blood was put into a plain bottle which had no anticoagulants in it for serum biochemical analysis. All blood samples were taken to the laboratory for analysis. The haemoglobin $(\mathrm{Hb})$ content was determined with a digital photo colorimeter (Model $312 \mathrm{E}$ by Digital Photo Instruments, Germany) at a wavelength of $625 \mathrm{~nm}$ and expressed in gramme (g) units. Packed cell volume (PCV) was determined through the Winthrosemicrohaematocrit technique, and expressed in percentages (\%). Red blood cell (RBC) counts was obtained with a Coulter Electronic counter (Model Z by Coulter Electronic Ltd. London), and the values were expressed in millions per microlitre $(\mu \mathrm{L})$ of blood $(x 106 / \mu \mathrm{L})$. The 


\section{Egbeyale, Ijaduola, Sogunle, Sonibare, Ayo-Ajasa and Adeleye}

total leucocytes or white blood cells (WBC) were counted with an improved Neubauer haemocytometer and expressed in thousands per microlitre $(\mu \mathrm{L})$ as described by Peters et al. (1982). Other haematological parameters that were computed include mean corpuscular volume (MCV), mean corpuscular haemoglobin (MCH) and mean corpuscular haemoglobin concentration (MCHC) were calculated from total RBC, $\mathrm{PCV}$ and $\mathrm{Hb}$ (Ritchie et al., 1994), respectively. Total protein was determined by the Biuret methodand serum cholesterol by the enzymatic colorimetric technique (Odoh and Bratte, 2015). Serum albumin was analyzed colorimetrically according to the method of Douma and Briggs (1972) and Peters et al. (1982). Globulin was estimated as the difference between total protein and albumin.

\section{Data analysis}

All data were subjected to one-way Analysis of Variance ANOVA as contained in SAS (2012). Means that were significantly $(p<0.05)$ different were separated by Duncan Multiple range test of the statistical software.

Table 1: Percentage composition of experimental diets (\%)

\begin{tabular}{lll}
\hline Ingredients & Starter & Finisher \\
\hline Maize & 47.00 & 53.50 \\
Soyabean Meal & 18.50 & 16.50 \\
Fish Meal & 2.00 & 0.40 \\
Groundnut Cake & 17.50 & 13.80 \\
Wheat Offal & 10.00 & 10.80 \\
Bone Meal & 3.00 & 3.00 \\
Oyster Shell & 1.00 & 1.00 \\
Vitamin Premix & 0.25 & 0.25 \\
Methionine & 0.25 & 0.25 \\
Lysine & 0.25 & 0.25 \\
Salt & 0.25 & 0.25 \\
Total & $\mathbf{1 0 0}$ & $\mathbf{1 0 0}$ \\
Calculated analysis & & \\
Crude protein $(\%)$ & 23.00 & 20.10 \\
Crude fibre $(\%)$ & 3.61 & 3.51 \\
Ether extracts $(\%)$ & 4.04 & 3.88 \\
Metabolisable energy $(\mathrm{MJ} / \mathrm{Kg})$ & 11.47 & 11.62 \\
\hline
\end{tabular}

\section{Results}

The result of effect of neem leaf aqueous extract on the growth performance of broiler chicks is shown in Table 2. At starter phase, there was no significant $(\mathrm{p}>0.05)$ difference in all the parameters measured except feed conversion ratio (FCR). Poorest feed conversion ratio $(1.59 \pm 0.04)$ was observed in birds that took water containing $50 \mathrm{mLs}$ neem leaf extract while the best $(1.48 \pm 0.02)$ was observed in the birds on 0 and $40 \mathrm{mLs}$ of neem leaf extract. At finisher phase, there was no significant $(p>0.05)$ difference in all parameters measured. The live weights ranged from 2067.63 (30 mLs/l) to $2175.59 \mathrm{~g}$. The daily feed and water intake ranged from 121.11 to $124.39 \mathrm{~g}$ and 346.47 to $362.40 \mathrm{mLs}$, respectively. 


\section{Air-dried neem leaf extract}

Table 2: Effect of air-dried neem leaf extract on growth performance ofbroiler chickens

\begin{tabular}{|c|c|c|c|c|}
\hline \multirow[b]{2}{*}{ Parameters } & \multicolumn{4}{|c|}{ Inclusion level of neem leaf extract (ml) } \\
\hline & $\mathbf{0}$ & 30 & 40 & 50 \\
\hline \multicolumn{5}{|l|}{ Starter Phase } \\
\hline Initial weight (g) & $38.30 \pm 0.51$ & $35.05 \pm 0.58$ & $38.48 \pm 0.99$ & $38.33 \pm 1.37$ \\
\hline Final weight $(\mathrm{g})$ & $1046.25 \pm 10.87$ & $1036.81 \pm 14.25$ & $1046.25 \pm 22.49$ & $1011.5 \pm 9.18$ \\
\hline Weight gain $(\mathrm{g})$ & $1007.95 \pm 10.764$ & $998.76 \pm 13.92$ & $1007.78 \pm 21.89$ & $973.20 \pm 9.58$ \\
\hline Daily weight gain (g) & $35.99 \pm 0.38$ & $35.67 \pm 0.49$ & $35.99 \pm 0.78$ & $34.76 \pm 0.34$ \\
\hline Total feed intake $(\mathrm{g})$ & $1491.95 \pm 11.58$ & $1545.60 \pm 15.59$ & $1495.78 \pm 33.50$ & $1547.64 \pm 25.03$ \\
\hline Daily feed intake (g) & $53.28 \pm 0.42$ & $54.13 \pm 0.56$ & $53.42 \pm 1.19$ & $55.27 \pm 0.89$ \\
\hline Total water intake (mLs) & $3394.43 \pm 17.00$ & $3388.21 \pm 21.08$ & $3290.14 \pm 62.36$ & $3397.87 \pm 31.68$ \\
\hline $\begin{array}{l}\text { Daily water intake } \\
(\mathrm{mLs})\end{array}$ & $121.23 \pm 0.61$ & $121.01 \pm 0.75$ & $117.51 \pm 2.23$ & $121.35 \pm 1.13$ \\
\hline Feed Conversion Ratio & $1.48 \pm 0.02^{\mathrm{b}}$ & $1.52 \pm 0.01^{\mathrm{ab}}$ & $1.48 \pm 0.02^{\mathrm{b}}$ & $1.59 \pm 0.04^{\mathrm{a}}$ \\
\hline \multicolumn{5}{|l|}{ Finisher phase } \\
\hline Final weight (g) & $2175.59 \pm 10.77$ & $2067.63 \pm 83.61$ & $2174.44 \pm 42.08$ & $2144.86 \pm 21.73$ \\
\hline Weight gain $(\mathrm{g})$ & $1129.34 \pm 15.91$ & $1030.83 \pm 85.60$ & $1128.19 \pm 57.99$ & $1133.33 \pm 27.85$ \\
\hline Daily weight gain $(\mathrm{g})$ & $53.78 \pm 0.76$ & $49.09 \pm 4.08$ & $53.72 \pm 2.76$ & $53.97 \pm 1.33$ \\
\hline Total feed intake $(\mathrm{g})$ & $2389.01 \pm 25.63$ & $2612.19 \pm 119.38$ & $2545.17 \pm 25.49$ & $2543.29 \pm 53.66$ \\
\hline Daily feed intake (g) & $113.76 \pm 1.22$ & $124.39 \pm 5.68$ & $121.19 \pm 1.21$ & $121.11 \pm 2.56$ \\
\hline Total water intake (mLs) & $7275.93 \pm 104.88$ & $7444.27 \pm 366.09$ & $7610.44 \pm 329.69$ & $7337.14 \pm 292.69$ \\
\hline $\begin{array}{l}\text { Daily water intake } \\
(\mathrm{mLs})\end{array}$ & $346.47 \pm 4.99$ & $354.49 \pm 17.43$ & $362.40 \pm 15.69$ & $349.39 \pm 13.94$ \\
\hline Feed Conversion Ratio & $2.16 \pm 0.01$ & $2.57 \pm 0.19$ & $2.27 \pm 0.12$ & $2.25 \pm 0.03$ \\
\hline
\end{tabular}

The effect of neem leaf extracts on haematological parameters of broiler chickens at starter and finisher phases are presented in Table 3. The haematological parameters were not significantly $(\mathrm{p}<0.05)$ influenced by the trial diets. At the starter phase, Packed Cell Volume (PCV) range was between 32 and $34.67 \%$ while White Blood Cell Count (WBC) ranged from 10.73 (30 mLs NLE) to $13.10 \times 10^{9} / 1$ (control). For the finisher phase, Red Blood Cell Count (RBC) ranged from $1.93(0 \mathrm{ml}$ NLE) to $2.27 \times 10^{9} / 1(50 \mathrm{ml} \mathrm{NLE})$ while the white blood cell ranged from 9.90 to $11.17 \mathrm{x}$ $10^{9} / 1$.

The effect of neem leaf extracts on serum indices of broiler chickens at starter and finisher phases are presented in Table 4. The results on the biochemical composition of the blood of the birds indicated that there was no significant $(\mathrm{P}>0.05)$ difference among the treatment groups in all the serum biochemical indices at both starter and finisher phase. Aspartate aminotransferase ranged from 68.67 (50ml NLE) and 81.00 $\mathrm{U} / 1$ (30ml NLE) while alanine transaminase ranged from 27.67 (30ml NLE) and 32.33 $\mathrm{U} / 1$ (50ml NLE). The values of globulin ranged from $1.20(50 \mathrm{ml} \mathrm{NLE})$ to $1.83 \mathrm{~g} / \mathrm{dl}$ (30ml NLE) while alanine transaminase ranged from $25.00(0 \mathrm{ml} \mathrm{NLE})$ to $34.00 \mathrm{U} / 1$ (30ml NLE). 


\section{Egbeyale, Ijaduola, Sogunle, Sonibare, Ayo-Ajasa and Adeleye}

Table 3: Effect of air-dried $n$ eem leaf extract on haematological parameters of broiler chickens

\begin{tabular}{|c|c|c|c|c|}
\hline \multirow[b]{2}{*}{ Parameters } & \multicolumn{4}{|c|}{ Inclusion level of neem leaf extract (ml) } \\
\hline & $\mathbf{0}$ & 30 & 40 & 50 \\
\hline \multicolumn{5}{|l|}{ Starter phase } \\
\hline Pack Cell Volume (\%) & $33.00 \pm 1.16$ & $32.33 \pm 2.60$ & $32.00 \pm 1.15$ & $34.67 \pm 0.67$ \\
\hline Haemoglobin $(\mathrm{g} / \mathrm{dl})$ & $9.73 \pm 0.37$ & $9.97 \pm 0.16$ & $9.97 \pm 0.32$ & $10.70 \pm 0.32$ \\
\hline Red Blood Cell $\left(\times 10^{12} / 1\right)$ & $2.73 \pm 0.03$ & $2.53 \pm 0.35$ & $2.43 \pm 0.30$ & $2.77 \pm 0.09$ \\
\hline White Blood Cell (x109/1) & $13.10 \pm 1.73$ & $10.73 \pm 0.94$ & $11.6 \pm 0.70$ & $11.2 \pm 0.45$ \\
\hline Heterophil $(\%)$ & $32.00 \pm 4.35$ & $37.33 \pm 4.18$ & $27.67 \pm 5.37$ & $30.67 \pm 5.81$ \\
\hline Lymphocyte (\%) & $69.33 \pm 2.40$ & $61.67 \pm 4.67$ & $69.67 \pm 6.07$ & $68.67 \pm 5.93$ \\
\hline Eosinophil (\%) & $0.00 \pm 0.00$ & $0.00 \pm 0.00$ & $1.00 \pm 0.58$ & $0.00 \pm 0.00$ \\
\hline Basophil (\%) & $0.33 \pm 0.33$ & $0.00 \pm 0.00$ & $0.67 \pm 0.33$ & $0.00 \pm 0.00$ \\
\hline Monocyte $(\%)$ & $1.67 \pm 0.33$ & $1.00 \pm 0.58$ & $1.00 \pm 0.58$ & $0.67 \pm 0.67$ \\
\hline $\operatorname{MCV}\left(u^{3}\right)$ & $120.85 \pm 5.50$ & $129.93 \pm 8.78$ & $134.59 \pm 13.63$ & $125.45 \pm 2.76$ \\
\hline $\mathrm{MCH}(\mathrm{pg})$ & $35.65 \pm 1.76$ & $39.63 \pm 1.25$ & $41.96 \pm 4.36$ & $38.74 \pm 1.58$ \\
\hline $\mathrm{MCHC}(\%)$ & $29.50 \pm 0.71$ & $30.65 \pm 0.12$ & $31.16 \pm 0.14$ & $30.86 \pm 0.61$ \\
\hline \multicolumn{5}{|l|}{ Finisher phase } \\
\hline Pack Cell Volume (\%) & $33.00 \pm 1.15$ & $33.67 \pm 1.67$ & $30.67 \pm 3.17$ & $33.00 \pm 2.08$ \\
\hline Haemoglobin $(\mathrm{g} / \mathrm{dl})$ & $10.33 \pm 0.80$ & $10.83 \pm 0.49$ & $9.67 \pm 1.01$ & $10.43 \pm 0.35$ \\
\hline Red Blood Cell (x10 $12 / 1)$ & $2.03 \pm 0.37$ & $2.43 \pm 0.33$ & $1.93 \pm 0.43$ & $2.27 \pm 0.12$ \\
\hline White Blood Cell (x109/1) & $10.53 \pm 0.37$ & $9.90 \pm 0.71$ & $10.63 \pm 1.01$ & $11.17 \pm 0.76$ \\
\hline Heterophil (\%) & $25.33 \pm 8.88$ & $26.00 \pm 3.00$ & $29.33 \pm 7.22$ & $22.33 \pm 6.36$ \\
\hline Lymphocyte (\%) & $71.00 \pm 7.50$ & $70.00 \pm 2.33$ & $69.67 \pm 6.64$ & $74.00 \pm 6.00$ \\
\hline Eosinophil (\%) & $1.33 \pm 0.67$ & $1.67 \pm 0.33$ & $1.00 \pm 0.58$ & $1.00 \pm 0.00$ \\
\hline Basophil (\%) & $0.33 \pm 0.33$ & $0.67 \pm 0.33$ & $0.33 \pm 0.33$ & $0.67 \pm 0.33$ \\
\hline Monocyte $(\%)$ & $2.33 \pm 0.88$ & $2.00 \pm 0.00$ & $1.33 \pm 0.67$ & $2.00 \pm 0.58$ \\
\hline $\operatorname{MCV}\left(\mathrm{um}^{3}\right)$ & $173.98 \pm 32.26$ & $141.37 \pm 11.01$ & $167.30 \pm 22.55$ & $145.44 \pm 1.48$ \\
\hline $\mathrm{MCH}(\mathrm{pg})$ & $59.38 \pm 3.61$ & $48.56 \pm 5.81$ & $47.72 \pm 3.18$ & $52.93 \pm 5.11$ \\
\hline $\mathrm{MCHC}(\%)$ & $31.21 \pm 1.37$ & $32.22 \pm 1.08$ & $31.52 \pm 0.44$ & $31.73 \pm 1.00$ \\
\hline
\end{tabular}

Table 4: Effect of air-dried n eem leaf extract on serum biochemical parameters of broiler chickens

\begin{tabular}{|c|c|c|c|c|}
\hline \multirow[b]{2}{*}{ Parameters } & \multicolumn{4}{|c|}{ Inclusion level of neem leaf extract (ml) } \\
\hline & $\mathbf{0}$ & 30 & 40 & 50 \\
\hline \multicolumn{5}{|l|}{ Starter phase } \\
\hline Total protein $(\mathrm{g} / \mathrm{dl})$ & $3.47 \pm 0.35$ & $2.90 \pm 0.44$ & $2.90 \pm 0.32$ & $2.90 \pm 0.10$ \\
\hline Albumin $(\mathrm{g} / \mathrm{dl})$ & $1.90 \pm 0.20$ & $1.73 \pm 0.32$ & $1.67 \pm 0.27$ & $1.70 \pm 0.15$ \\
\hline Globulin $(\mathrm{g} / \mathrm{dl})$ & $1.50 \pm 0.15$ & $1.17 \pm 0.13$ & $1.30 \pm 0.12$ & $1.40 \pm 0.06$ \\
\hline Uric acid (mg/dl) & $9.90 \pm 0.38$ & $9.50 \pm 0.85$ & $8.93 \pm 0.84$ & $9.60 \pm 0.10$ \\
\hline Glucose $(\mathrm{g} / \mathrm{dl})$ & $90.67 \pm 8.82$ & $91.67 \pm 4.05$ & $88.00 \pm 6.93$ & $94.00 \pm 5.13$ \\
\hline Creatinine (mg/dl) & $0.67 \pm 0.29$ & $0.77 \pm 0.13$ & $0.73 \pm 0.09$ & $0.80 \pm 0.28$ \\
\hline Cholesterol (mg/dl) & $124.00 \pm 3.06$ & $124.00 \pm 8.74$ & $119.00 \pm 6.56$ & $119.00 \pm 5.49$ \\
\hline Aspartate aminotransferase (U/1) & $73.33 \pm 0.33$ & $81.00 \pm 2.65$ & $70.67 \pm 5.81$ & $68.67 \pm 3.76$ \\
\hline Alanine transaminase $(\mathrm{U} / \mathrm{l})$ & $30.33 \pm 6.06$ & $27.67 \pm 2.96$ & $30.67 \pm 2.96$ & $32.33 \pm 2.60$ \\
\hline Alkaline phosphatase (U/l) & $29.33 \pm 1.76$ & $27.67 \pm 4.81$ & $25.00 \pm 2.65$ & $27.33 \pm 3.18$ \\
\hline \multicolumn{5}{|l|}{ Finisher phase } \\
\hline Total protein $(\mathrm{g} / \mathrm{dl})$ & $3.30 \pm 0.26$ & $3.80 \pm 0.29$ & $2.97 \pm 0.27$ & $3.03 \pm 0.29$ \\
\hline Albumin $(\mathrm{g} / \mathrm{dl})$ & $1.87 \pm 0.19$ & $1.97 \pm 0.12$ & $1.67 \pm 0.17$ & $1.83 \pm 0.41$ \\
\hline Globulin (g/dl) & $1.43 \pm 0.18$ & $1.83 \pm 0.22$ & $1.30 \pm 0.10$ & $1.20 \pm 0.15$ \\
\hline Uric acid (mg/dl) & $9.30 \pm 0.80$ & $8.87 \pm 0.20$ & $8.87 \pm 0.57$ & $9.50 \pm 0.47$ \\
\hline Glucose (g/dl) & $82.33 \pm 4.98$ & $86.00 \pm 7.02$ & $72.33 \pm 2.67$ & $86.33 \pm 6.44$ \\
\hline Creatinine $(\mathrm{mg} / \mathrm{dl})$ & $0.53 \pm 0.19$ & $0.57 \pm 0.19$ & $0.53 \pm 0.17$ & $0.77 \pm 0.37$ \\
\hline Cholesterol (mg/dl) & $122.33 \pm 1.20$ & $121.33 \pm 8.29$ & $128.67 \pm 3.71$ & $129.00 \pm 2.65$ \\
\hline Aspartate aminotransferase (U/1) & $69.00 \pm 7.64$ & $66.33 \pm 4.33$ & $67.67 \pm 4.33$ & $66.00 \pm 1.53$ \\
\hline Alanine transaminase $(\mathrm{U} / \mathrm{l})$ & $25.00 \pm 3.21$ & $34.00 \pm 4.16$ & $32.00 \pm 4.36$ & $28.67 \pm 1.86$ \\
\hline Alkaline phosphatase (U/1) & $21.67 \pm 2.67$ & $20.67 \pm 1.76$ & $26.00 \pm 1.00$ & $25.33 \pm 3.84$ \\
\hline
\end{tabular}




\section{Air-dried neem leaf extract}

\section{Discussion}

The live weight and weight gains of the birds in this study were higher than the values reported by Egbeyale et al. (2015). The authors observed that neem leaf meal inclusion higher than $0.5 \%$ in the diet of broiler birds reduced weight gain. The comparable weight gain of the birds fed neem leaf extract and the control is an indication that quantity of toxic factors such as terpenes and limonoids was minimal to have depressed the growth of the birds. This corroborates the findings of Verma et al. (1998) who had earlier reported insignificant difference in weight gain of chicks fed raw and alkali treated neem kernel meal. The weight gain recorded in this study has further revealed the potentials in leaf extracts as source of nutrients needed by animals and as growth promoter. The results of present study disagree with the findings of Chakeravarty and Prasad (1991) and Durrani et al. (2008), on improved body weight gain in broiler chickens fed diets containing neem leaves and neem leaf infusion, respectively had. The similarity in water consumption observed in this study was not in accordance with the report of Durrani et al. (2008) who reported significant difference in the water intakes of the treated groups and the control. The differences in the results of the growth indices could be attributed to the processing method of the neem leaves before extraction. Durrani et al. (2008) oven dried the leaves while the leaves were air-dried in this present study. The difference in feed conversion ratio among the treatments shows that the neem leaves extract had effect on nutrient availability, digestion, absorption and utilization. The poor utilization of diets containing higher levels of neem leaf extract at starter phase might be related to the inability of the bird's enzyme to break down the active and improper metabolism associated with the neem leaf as reported by Esonu et al. (2005).

The similarity in haematological indices across treatments indicate the wellness of the birds throughout the period of the experiment as normal haematological parameters of an animal are direct indication of absence of disease (Olafedehan, 2010). The values obtained were within the normal range for healthy birds as stated by Mitruka and Rawnsley(1977). This indicates that these animals were not stressed due to inclusion of the leaf extract. These results similar with those observed by Olugbemi et al. (2010) that packed cell volume was not affected due to the supplementation of Neem (Azadirachta indica) leaf extract. However, the result disagreed with that of Nagalakshmi et al. (1996) who reported that neem possesses strong influence on the haematological traits in broilers particularly haemoglobin. Sadre et al. (1984) and Gowda et al. (1998) also reported that neem preparations fed to laying hens significantly reduced the content of haemoglobin, erythrocyte count and packed cell volume. The variations observed by the authors on the haematological effect of neem extracts may however depend on the mode of application, concentration and exposure time.

Serum biochemical investigations have been explored extensively to distinguish normal state from stress and disease conditions in animals. The similarities in all the serum biochemical indices in this study did not agree with the earlier work of Biuet al. (2009) who reported a significant increase in serum creatinine and urea levels on the administration of neem leaves aqueous extract on broiler birds intraperitoneally. He ascribed it to the fact that neem leaf aqueous extract has proven to be toxic to both the liver and kidney of chicken. In another study on rabbit, 
Ogbuewu et al. (2008) attributed the significant effect of neem leaves on serum creatinine and urea level to the presence of some bioactive compounds (Azadirachtin, Nimbin, Salanin) which have been reported to block the energy metabolic pathway in animals, thus making it difficult for the animals to meet their energy requirement. The variation observed by the author might be due to the mode of application and basis of administration (dose per body weight). This finding also did not support the findings of Oyagbemi and Adejinmi (2012) who reported decline in glucose level using neem leaves extract in broiler production. The findings of the present study were not in line with the findings of Nagalakashmi et al. (1996) who used a diet containing different levels of urea ammoniated neem kernel cake as a protein supplement to replace peanut meal. The authors found that blood urea level of birds increased as the amount of urea treated neem was increased in the diet. The variation with this study could be as a result of the level or form of application (urea treated neem kernel against leaf extract).

\section{Conclusion}

It can be concluded from the result of this study that administration of $4 \%$ aqueous air-dried neem leaf extract in the drinking water of broiler chickens had no toxic effectson the growth response, haematological parameters and serum metabolites. Therefore, it can serve as alternative to antibiotics in commercial broiler production

\section{References}

Biu, A. A., Yusufu, S. D. and Rabu, J. S. 2009. Studies on the effects of aqueous leaf extracts of neem (Azadirachta indica A. Juss) on haematological parameters in chicken. African Journal of
Science and Technology, 10 (4): 189-192.

Chakarverty, A. and Parsad, J. 1991. Study on the effect of neem leaf extract and neem cake extract on the performance of broiler chicks. Indian poultry Adviser. 24(9): 3738.

Durani, F.R., Chand, N., Jan, M., Sultan, A., Durani, Z. and Akhter, S. 2008. Immunomodulatory and growth promoting effects of neem (Azadirachta indica) leaves infusion in broiler chicks. Sarhad Journal of Agriculture, 24(4): 655659.

Egbeyale, L. T., Ayo-Ajasa, O. Y., Ayoola, A. A., Ogunkunle, N. F. and Okuboyejo, O. A. 2015. Performance of broiler chickens fed neem (Azadirachta indica) leaf meal as an alternative to antibiotics. Bulletin of Animal Health and Production in Africa, 63(4): 403410.

Esonu, B.O., Emenalom, O.O., Udedibie, A.B.I., Anyanwu, G.A., Madu, U. and Inyang, A.O. 2005. Evaluation of neem (Azadirachta indica) leaf meal on performance, carcass characteristics and egg quality of laying hens. International Journal of Agricultural Development. 6: 208212.

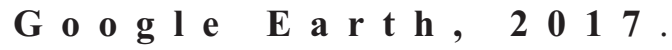
www.googleearth.com

Gowda, S. K., Verma, S. V. S., Elangovan, A. V. and Singh, A. D. 1998. Neem(Azadirachta indica) kernel meal in the diet of white leghorn layers. British Poultry Science. 39(3): 648-652.

Kale, B. P., Kothekar, M. A., Tayade, H. P., Jaju, J. B. and Mateenuddin, M. 2003. Effect of aqueous extract 
of Azadirachta indica leaves on hepatotoxicity induced by antitubercular drugs in rats. Indian Journal of Pharmacology 35(3): 177-180

Mitruka, B. M., Rawnsley, H. M. and Vadehra, B. V. 1977. Clinical biochemical and haematological reference values in normal experimental animals. Masson Publishing USAInc. 272.

Nagalakshmi, D., Sastry, V. R. B., Agrawal, D. K., Ketiyar, R. C. and Verma, S. V. S. 1996. Performance of broiler chicks fed on alkali-treated neem (Azadirachta indica) kernel cake as a protein supplement. British Poultry Science, 37:809 - 818.

Nayaka, H. B. S., Umakantha, B., Ruban, S. W., Murthy, H. N. N., Narayanaswamy, H. D. 2012. Effect of neem, Turmeric, Vitamin $\mathrm{E}$ and their combinations on immune response in broilers. Global Vaterinaria, 9: 486-489.

Ogbuewu, I. P. 2008. Physiological responses of rabbits fed graded levels of neem (Azadirachta indica) leaf meal. M.Sc. Thesis, Federal University of Technology, Owerri, pp: 51.

Olafedehan, C. O., Obun, A. M., Yusuf, M. K., Adewumi, O. O., Oladefedehan, A. O., Awofolaji, A. O., and Adeniji, A. A. 2010. Effects of residual cyanide in processed cassava peal meals on haematological and biochemical indices of growing rabbits. Proceedings of 35th Annual Conference of Nigerian Society for Animal Production, p. 212-215.

Olugbemi, T. S., Mutayoba, S. K. and Lekile, F. P. 2010. Effect of Moringa (Moringa oleifera) inclusion in cassava-based diets fed to broiler chickens. International Journal of Poultry Science, 9: 363367.

Oyagbemi, T. O. and Adejinmi, J. O. 2012. Supplementation of broiler feed with leaves of Vernonia amygdalina and Azadirachta indica protected birds naturally infected with Eimeria sp. African Journal of Biotechnology, 11 (33): 8407-8413.

Sadre, N. L., Deshpande, V. Y., Mendulkar, K. N. and Nandal, D. H. 1984. Male anti-fertility activity of Azadirachta indica A. Juss (Neem) in different species. In: Schmutterer $\mathrm{H}$ and Ascher KRS. eds. Natural pesticides from the Neem tree (Azadirachta indica. A. Juss) and other tropical plants. CRC Press, Boca Raton, Florida, U.S.A.p. $473-482$

SAS 2012. Statistical Analysis System. SAS Version 9.2 user's guide. Cary, NY: SAS institute.

Verma, S. V. S., Gowda, S. K. and Elangovan, A. V. 1998. Response of single comb white leghorn layers to dietary inclusion of raw and alkali treated neem kernel meal. Animal Feed Science and Technology, 76: 169-175.

Received: $18^{\text {th }}$ June, 2018 Accepted: $21^{\text {st }}$ December, 2018 